10 years ESJ

Special edition

\title{
Responding in a Pandemic: Student Nurse Educator Mentorships, the Other Side of Blackboard
}

\author{
Audrey Tolouian, EdD, RN, CNE \\ Diane B. Monsivais, PhD, RN, CNE, ANEF \\ Melissa Wholeben, PhD, RN, CNE, TCRN
}

School of Nursing, The University of Texas at El Paso, El Paso, TX, U.S.A.

Doi: $10.19044 /$ esj.2021.v17n30p53

Submitted: 11 June 2021

Accepted: 09 August 2021

Published: 10 September 2021
Copyright 2021 Author(s)

Under Creative Commons BY-NC-ND

4.0 OPEN ACCESS

Cite As:

Tolouian A., Monsivais D.B. \& Wholeben M. (2021). Responding in a Pandemic: Student Nurse Educator Mentorships, the Other Side of Blackboard. European Scientific Journal, ESJ, 17 (30), 53. https://doi.org/10.19044/esj.2021.v17n30p53

\section{Abstract}

Background: Nurse educators who are novice often express the need for improved preparation in the educator role. Problem: With the growth of online programs, one area of concern is the need for educators who are prepared to teach online. Approach: A mentorship for online teaching was developed to give student nurse educators the opportunity to develop educator competencies in the online environment. The process, benefits, challenges, and key points for the success of the mentorship are discussed. Outcomes: Since Spring 2016, 89 nurse educator graduate students have completed the mentorship. Their confidence related to the educator role in an online environment was enhanced, and they took great pride in serving as professional role models to the undergraduate nursing students. Conclusions: The mentorship option provides improved educator role preparation for nursing education graduate students who will teach online. It also provides informal mentorship as well as an unexpected perceived value in higher education to students in undergraduate nursing program.

Keywords: Online Education, Graduate Nursing Education, Mentorships, Faculty 


\section{Introduction}

Nurse educators who are novice frequently express the need for improved skills and confidence in the educator role. A review of literature suggests that there is an urgent need for improved role preparation and mentoring in the educator role (Cotter \& Clukey, 2019; Grassley \& Lambe, 2015). With the growth of online programs in nursing education, one area of concern is the need for educators who are prepared to teach online. Graduate faculty developed a mentorship option to address the need for improved role preparation in teaching online courses to education students for Master of Science in Nursing (MSN). Graduate level advanced practice courses are taught specifically for educators, and there is a focus on integration of best practices in simulation pedagogy throughout the curriculum (UTEP, 2020).

Experienced undergraduate faculty are mentors for the MSN-Educator students in both an online RN-BSN (Registered Nurse to Bachelor of Science Nurse) program and in a pre-licensure program. The MSN students are always quick to appreciate the vast difference in being a student and being a faculty member in the online learning management system, and student feedback has defined the experience as being "on the other side of Blackboard." The students develop nurse educator competencies, which allows them to identify their focus areas of special interest (UTEP, 2020).

After describing the program partners in the mentorship, this study will discuss the process, benefits, challenges, key points for success, and outcomes that allows faculty mentor MSN Nursing Education students to teach online classes.

\section{Background}

With the new COVID-19 (Coronavirus Disease 2019) environment, several facets of the academic environment have changed to virtual learning modes. This involves the MSN-Educator student's practice interactions. Students were able to select a teaching environment at their place of work or a virtual one in the RN-BSN (Registered Nurse to Bachelor of Science Nurse) program of The University of Texas, El Paso, prior to the COVID-19 pandemic. COVID-19 restrictions on clinical sites created an increased need for educator skill in the online environment. For example, for the undergraduate pre-licensure BSN (Bachelor of Science Nurse) student, instead of hands-on simulation/clinical, clinical practice was in the format of virtual clinicals. This created a need for the MSN-Educator student to remotely teach their students while addressing clinical outcomes. This mentorship is one option that is available to MSN students to complete their mentorship hours. It also provides the opportunity for MSN students to develop competencies and improve their confidence in online pedagogy. Furthermore, this serves as 
professional role models and mentors to BSN students in both prelicensure and RN-BSN courses.

The mentorship aligns with the AACN (American Association of Colleges of Nursing) MSN Essentials (AACN, 2011) and the National League for Nursing, i.e., Nurse Educator Competencies (National League for Nursing, 2012). While the Nurse Educator Competencies and task statements are not specific to online teaching, they correspond with the Online Learning Consortium's Quality Course Teaching and Instructional Practices (Online Learning Consortium, 2019).

The following table provides an example:

Table 1.

\begin{tabular}{|l|l|}
\hline \multicolumn{2}{|c|}{ Competency: Facilitate Learning } \\
\hline NLN Nurse Educator Task Statements & $\begin{array}{l}\text { Online Quality Course Teaching and } \\
\text { Instructional Practices }\end{array}$ \\
\hline $\begin{array}{l}\text { Uses information technologies skillfully to } \\
\text { support the teaching learning process }\end{array}$ & Instructor facilitates critical thinking \\
$\begin{array}{l}\text { Creates learning environments that are } \\
\text { focused on socialization to the role of the } \\
\text { nurse and facilitate learners' self-reflection } \\
\text { and personal goal setting }\end{array}$ & $\begin{array}{l}\text { Instructor provides prompt feedback. } \\
\text { in performing successfully in the course. }\end{array}$ \\
\hline \multicolumn{2}{|c|}{ Competency: Use Assessment and Evaluation Strategies } \\
\hline $\begin{array}{l}\text { NLN Nurse Educator Task Statements } \\
\text { Provides timely, constructive and thoughtful } \\
\text { feedback to learners }\end{array}$ & $\begin{array}{l}\text { Online Quality Course Teaching and } \\
\text { Instructional Practices }\end{array}$ \\
\hline $\begin{array}{l}\text { Instructor provides clear, useful, and } \\
\text { constructive feedback to students. }\end{array}$ \\
$\begin{array}{l}\text { Instructor demonstrates presence by engaging } \\
\text { actively and frequently throughout the course }\end{array}$ \\
\hline
\end{tabular}

\section{Program Partners in Mentorship}

The MSN Nursing Education program is a 33-credit hour program that spans over two calendar years at a public university in the Southwest. The last course in the MSN program is an experiential course that explains the roles of a nurse educator, and students are given the option to develop competencies in the educator role in an online environment. This is achieved through mentoring with faculty who teach in the online RN-BSN program. Online courses are also offered in the pre-licensure program. 
Enrollment in the MSN in Nursing Education program averages 80 students per semester, with typically 8-10 MSN students in the last course of the program who wish to use this option to complete their practicum hours. The BSN degree programs include both a pre-licensure program that is primarily on-campus, but it also includes a few online courses and an RN-BSN fully online program. Enrollment in the pre-licensure program averages 360 - 400 per semester, with approximately 30 students in each section of an online course per semester.

On the other hand, enrollment in the RN-BSN program averages 120150 students per semester, with approximately 25-30 students in each section of a course per semester.

\section{Process}

During the semester prior to the educator roles course, the director of the MSN in Nursing Education program usually posts a sign-up list (in Blackboard, the course management system used by the University) explaining the mentorship experience. Once the sign-up period is finished, the director sends the names and contact information to the undergraduate faculty coordinator who then reviews upcoming courses and faculty assignments

Thereafter, emails are sent to the interested MSN students for the upcoming semester, which shows them the available courses. The number of MSN students placed depends on the number of courses and how many sections of each course are offered during the semester. The same faculty member may be teaching multiple sections, which allows mentorship to occur for more than one MSN student at a time.

In the past, the faculty coordinator scheduled phone interviews with each MSN student prior to course placement. Although this was a wonderful way to establish rapport and identify the students' strengths with specific content as well as their objectives for the experience, time constraints however made it impractical. The "interview" process now takes place by email and has proven to be surprisingly effective. The students provide their brief professional background, which course they would be interested in, and why they think they would be a good fit for the course.

The MSN student receive a short 1:1 orientation about best practices in online teaching and the requirements of both the faculty and MSN students. This allows time for discussion and questions prior to the course start. The verbal or web-guided orientation consists of navigating Blackboard. This involves time requirements of how long MSN students should be engaged with the course per day, how to handle student concerns, as well as general course requirements. Each MSN student is expected to read and sign a list of duties so that expectations are clear. They can also estimate the time that should be allotted for the experience daily, and what they can expect from the 
undergraduate faculty is also included. The same document related to expectations is used in the wrap-up evaluation, thereby providing consistency throughout the process.

Individual tele-conferences between undergraduate faculty and MSN students are held weekly, with more communication occurring throughout the week when needed. The MSN students increase the number of supervised online teaching responsibilities throughout the course. During the first week, the course syllabus and calendar is reviewed. A guide on how to access the course materials and discussion board postings is also provided. Faculty mentors' model effective feedback and grading to the MSN-Educator students. MSN students usually have many questions about communicating with the students in the online environment, which results in robust discussions An example of this would be an MSN student who is grading discussion forums and determines that a participant is not answering the question appropriately, and/or going off on a tangent. The instructor and the MSN student would then discuss the concern, how to approach it from a faculty point of view, and give positive feedback with ways to improve.

One area that is often difficult is dealing with student conflict and resolution. For example, BSN students will often challenge a grade, and the MSN student must be prepared to defend the grade awarded. Furthermore, faculty mentors have developed standard "Hints for Grading Comments" that guide the process. The MSN students utilize links to APA (American Psychological Association) materials while grading student assignments.

\section{Benefits}

The online environment allows students to develop competencies in online teaching, which is a much-needed skill for future educators. The MSN students frequently express that such aspects of the online environment were unexpected, and that it was much more challenging than a traditional face- toface class. Communication, course preparation, and the increased amount of time necessary for the virtual classroom were some of the unexpected aspects. This prelude in a mentored environment has provided a realistic experience, which allows them to make an educated job choice after graduation about whether being on "the other side of Blackboard" was a good match for them. Many have provided feedback in course evaluations that they would not have stayed in the experience if they did not work with faculty mentors who were immediately accessible. When students are given an opportunity to experience online nursing academia, they are likely to continue online teaching after graduation.

One of the unexpected benefits of this initiative is that the MSN students share a wealth of knowledge with the BSN students during the mentorship practicum. Undergraduate student course evaluations state that the 
mentorship creates a highly interactive, collaborative peer-role model environment. The MSN students can give educational advice such as the best platforms for working in groups for school, how to manage courses while juggling work, family and school, as well as motivational support. Feedback from students include:

"An "A-ha moment" I had this week was that my tendency to be exacting could become problematic as an educator. I have so far had an idealized vision of what a great educator is, yet I realized that I could potentially be a colossal failure as an educator if I do not learn how to chill out. That's my takeaway for this week."

"The significance of this experience for me has been my growing feelings of confidence in taking on the role of teaching. I didn't expect to enjoy it so much, and the experience encouraged me to apply for teaching positions in nursing education. I feel like I know it's what I want to do, which is both exciting and encouraging. Being able to facilitate a nursing student to take a different view, or to understand new material, or to take a different perspective on the responsibility of the profession is very exciting. It is also interesting to gain experience with learners from diverse backgrounds, and to help them incorporate that diversity into their practice."

\section{Challenges}

Correct student placement is the initial challenge. Although the faculty coordinator has an initial email interview with each student for their desired course, it is sometimes still difficult to determine the best match of courses. However, giving students the opportunity to match their own skills to upcoming courses is the first step in overcoming the challenge.

Full-time faculty are the only eligible mentors. As a result, there was a challenge in placements during semesters with large MSN student cohorts. When this occurred, the faculty members took two MSN students per class. The time spent with each MSN student remained the same, thereby doubling the mentor's responsibilities. The faculty mentors found this to be a challenge but also found some benefits in this. For instance, the MSN students became a bit more independent with solving problems since they worked together as a team, and they were also quick in building rapport with the BSN students.

Nonetheless, maintaining MSN student engagement in the course was occasionally a challenge. Some students initially requested online teaching. However, as the course progressed, they decided that online teaching was not for them. This often happened when expectations were not clear. As a result, a clear delineation of expectations is presented during the orientation and review of expectations. Faculty also meet with the students to encourage them and offer some new opportunities such as course creation, assignment design, or aligning goals and outcomes. Nevertheless, online teaching is not for 
everyone. When it seems that an MSN student is struggling, the faculty tries to increase contact through phone calls, text messages, and individual meetings are set up. Students are further encouraged to ask questions and talk about what they think creates barriers in their learning. They are also asked what the faculty member can do to support them so that they can meet their objectives.

Additional challenges posed by the MSN students include time management and mentoring. Some examples can be seen through these statements: "I'm pretty sure that the students are the ones teaching me this week. I'm kinda exhausted" and "Previously, my work schedule worked around posting assignments in my own courses, but now in an educator role everything shifts a couple of days to allow students time to post and submit their assignments. I had not foreseen this change. My biggest challenge is defining a specific time frame to do all the grading and sticking to the designated time."

\section{Key Points for Success}

Clear and timely communication processes between the MSN program director and BSN faculty coordinator are essential. Prior to the start of the semester, matching MSN students with upcoming courses and giving orientation based on expectations is key to ensure that everything is in place when the semester begins. During the mentorship, faculty must provide ongoing, timely feedback and hold weekly meetings with the MSN students to facilitate learning and engagement.

\section{Outcomes}

Since Spring 2016, 89 MSN students have completed the mentorship and provided enthusiastic feedback during program evaluation about the experience of being "on the other side of Blackboard." All MSN students completed a course mentor feedback document that asked how satisfied they were with components of their teaching experience such as availability of mentor and interactions with students and mentor. In addition, the students provided feedback on the opportunity to implement the role of a nurse educator in classroom/clinical instruction, use critical thinking skills, participate in faculty governance, and meet course objectives of the practicum. Feedback included a positive trend in "confidence related to the online environment". They also took "great pride in serving as professional nursing role models and guiding the next generation of BSN students". The end of course evaluations also showed positive student learning experiences regarding opportunities available during the mentorship. Surprisingly, even some students who did not like teaching online rated the experience as a 
positive one. They were glad to find out early in their nursing education career that online teaching was not a good fit for them

In addition, the partnership serves as an excellent resource for identifying potential future faculty for the undergraduate program. Currently, two MSN program graduates are part-time faculty in the RN-BSN program. Conversely, approximately $11 \mathrm{MSN}$ program graduates are either part-time or full-time clinical instructors for the pre-licensure BSN program. Although the data related to success in online teaching compared to students who did not participate in the mentorship is not available, students still continually give feedback that the mentorship experience provided improved role preparation for teaching. In addition, they rank the experience as one they value highly.

\section{References:}

1. AACN (2011). The essentials of master's education in nursing. Retrieved from http://www.aacn.nche.edu/educationresources/MastersEssentials11.pdf

2. Cotter, K.D. \& Clukey, L. (2019). "Sink or Swim.” An ethnographic study of nurse educators in academic culture. Nursing Education Perspectives, 40(3), 139-143.

3. Grassley, J.S. \& Lambe, A. (2015). Easing the transition from clinician to nurse educator: An integrative literature review. Journal of Nursing Education, 54(7), 361-366.

4. National League for Nursing (2012). The scope of practice for academic nurse educators 2012 revision. New York: Author.

5. Online Learning Consortium (2019). Quality Scorecard Suite https://onlinelearningconsortium.org/consult/olc-quality-scorecardsuite/

6. University of Texas at El Paso (2020). Enrollment and Graduation $\mathrm{RN}$ to Baccalaureate Enrollment Statistics. 